\title{
ERŐVISZONYOK AZ ÉLELMISZERIPARI ELLÁTÁSI LÁNCBAN
}

A gyorsan változó piaci igények, illetve az ellátásilánc-menedzsment kritikus szerepe az igényeknek való megfelelésben, valamint az integrált ellátási láncok nyújtotta potenciális elônyök mind olyan tényezók, amelyeket a vállalatok ma már nem hagyhatnak figyelmen kívül. Ugyanakkor ezek az elónyök csak akkor realizálhatók, ha az ellátási lánc egyes szereplői között kellố szorosságú együttmúködési formák alakulnak ki. A partnerkapcsolatok ellátási lánc mentén történó kialakítását azonban döntốen befolyásolják a lánctagok közötti erôviszonyok. A tanulmány az FMCG/Food szektor ellátási láncaira jellemző hatalmi viszonyokkal foglalkozik, különös tekintettel arra, hogy az eróviszonyok miként befolyásolják a szektor kis- és középvállalkozásainak múködését, partnerkapcsolatait. A nemzetközi kutatási eredményeket alapul véve az élelmiszer-ipari KKV-k körében végeztek kérdốíves lekérdezést a szerzók. Ennek eredményeit felhasználva, a partnerkapcsolatokban megnyilvánuló hatalmi viszonyok és a vállalati jövedelmezôség, illetve néhány egyéb ellátási láncbeli sajátosság (a kapcsolatok szorossága, tartóssága, információmegosztási hajlandóság stb.) ellentmondásos viszonyát mutatják be.

\section{Kulcsszavak: ellátási lánc, hatalmi viszonyok, élelmiszeripar, kis- és középvállalatok}

A logisztikai/disztribúciós menedzsmentbeli kutatások elôtérbe kerülését (1980-as évek) alapvetôen két tényezô eredményezte. Az egyik azon követelmény, miszerint csökkenteni kell a készleteket és a nem értékteremtő tevékenységeket, a másik pedig a disztribúciós csatorna (az ellátási lánc) több szintjén jelen lévő kereskedők dominanciájának drasztikus növekedése, és az ennek eredményeképpen átrendeződő „hatalmi” viszonyok.

Napjainkban az ellátási láncok valamennyi tagja profitját igyekszik maximalizálni, úgy is, hogy kihasználja saját érdekérvényesító képességét, azaz hatalmát. A beszállítók abban érdekeltek, hogy saját meglévő outputjaikhoz igazítva szállítsanak és minél magasabb árat kapjanak termékeikért/szolgáltatásaikért. A gyártók célja, hogy termékeiknek ,legyen hely a kereskedôk polcain”, és hogy még éppen elegendő (de nem túl sok) terméket tudjanak elóállítani úgy, hogy sosem legyen készlethiány a polcokon. A kereskedők célja, hogy leginkább azokat a termékeket értékesítsék, amelyek a legmagasabb profitot biztosítják számukra, miközben beszállítóiktól alacsony árszinten kapják termékeiket. Gyakorlatilag valamennyi csatornatag rendelkezik kisebb vagy nagyobb hatalommal, aminek eredményeképpen folyamatos „hatalmi játék” zajlik az ellátási hálózatban.

\section{Szakirodalmi áttekintés}

\section{A hatalom szerepe az ellátási láncban}

$\mathrm{Az}$ ellátási láncbeli hatalom tulajdonképpen nem más, mint az a képesség, hogy egy lánctag hogyan képes befolyásolni a többi lánctag döntéseit, illetve menynyiben tudja saját érdekeit érvényesíteni. A hatalom valamennyi partnerkapcsolatnak eleme. Gelei (2003) szerint a lánctagok közötti hatalmi viszonyokat alapvetően az alábbi tényező́k határozzák meg:

- a vevő́k/beszállítók száma,

- a partner kibocsátásból/megrendelésból való részesedésének aránya,

- a partnerváltás költségei,

- termékjellemzók - múködési kompetencia jellemzói,

- együttmúködési jellemzók,

- információs aszimmetria,

- tranzakció, kapcsolatspecifikus beruházás mértéke,

- vertikális integrációval való fenyegetés mértéke. 
A csatornában betöltött hatalmi pozíció döntő szerepet játszhat az ellátási lánc integrációjában, hiszen befolyásolja a lánctagok közötti bizalmat, az együttmúködések iránti elkötelezettséget, az esetleges konfliktusokat és azok kezelését, megoldását (Barber, 2011). Így az ellátási láncok múködését döntôen befolyásolja az ún. csatorna-integrátorok jelenléte és tevékenysége. A csatorna-(vagy rendszer-)integrátorok szervezik az ellátási láncbeli folyamatokat, és ók alakítják ki a lánc stratégiáját, továbbá általában közvetlen kapcsolatban állnak a lánc kulcsszereplóivel. Skjott-Larsen (2006) szerint a csatornaintegrátorok hatalma alapvetóen a vásárlóerejükre, valamint a szabadalmazott technológiákhoz és tudáshoz való hozzáférés lehetőségére vezethető vissza. Mukhtar és Shaharoun (2002) szerint a rendszerintegrátorok hatalmukat jellemzően a következő területeken gyakorolhatják: az árképzés, a készletgazdálkodás, a gyártás, az ellátási lánc struktúrájának és az információáramlásnak a befolyásolása, irányítása. Véleményük szerint az, hogy a domináns csatornatagok mennyiben képesek a késleltetést és egyéb, spekulatív ellátásilánc-stratégiákat alkalmazni, az erőfölényük mértékének ,mutatószáma” lehet.

Brown et al. (1995) kutatási eredményei szerint a domináns csatornatag hatalmának gyakorlásával valamennyi csatornatag teljesítménye javulhat. Ezzel szemben Vereecke és Muylle (2006) szerint a domináns csatornatagok tevékenységéból gyakran hátránya származik az ellátási lánc többi tagjának. Véleményük szerint akkor sem feltétlenül növekszik a lánctagok teljesítménye, ha a domináns tag jól menedzseli ellátási láncbeli partnerkapcsolatait. Hasonlóan érvelnek Simatupang et al. (2004), miszerint a kiskereskedelmi láncok (mint domináns csatornatagok) piaci erófölényüknek köszönhetôen magasabb készletezési költségeket és az információs technológiába történô beruházásokat kényszerítenek beszállítóikra.

Barber (2011) szerint az ellátási láncban elméletileg négy csatornatagtípus tölthet be domináns szerepet.

1. Gyártóközpontú dominancia. Napjainkban a tartós fogyasztási cikkek láncaiban általában a gyártó vállalatok (OEM-ek) az agilis csatorna tagjai, melyek pull-rendszeren és késleltetésen alapuló stratégiát alkalmazva igyekeznek rugalmasan reagálni a gyakran változó fogyasztói igényekre. A rendszerintegrátorok tipikus példáját jelentik az európai autóiparban (amely döntôen piramiselven épül fel) az összeszerelést végzố autógyárak. Az autóipari láncokban megfigyelhetô, hogy a dominancia-hierarchia csúcsán a márkanevet tulajdonló, illetve az összeszerelő üzemet és a fejlesztési és értékesítési stratégiát is kézben tartó cég áll. Ezt követik a vele közvetlen kapcsolatban álló cégek, upstream oldalon az elsô szintú beszállítók, illetve downstream oldalon az elsố szintú vevốk. Ez utóbbiak „diktálnak" tovább lefelé. Az OEM azonban ,át is nyúlhat az elsô szintú csatornatagok feje felett", és megszabhatja, hogy például egy első szintú beszállító mely másodszintú beszállítókkal kössön beszállítói szerződést. Minél lejjebb haladunk a beszállítói piramisban, annál kisebb értékú és bonyolultságú termékekkel és vállalatméretekkel találkozhatunk (Demeter et al., 2004; Szegedi, 2012).

2. Beszállító-központú dominancia. A beszállítói dominancia gyakran valamilyen eróforrás-függőség következménye. Cox et al. (2003) kutatásai szerint a beszállítói dominancia forrásai a következók lehetnek: tulajdonjogok, méretgazdaságosság, hírnév (például márkázás), partnerváltás költsége, partnerkeresés költsége vagy összejátszáson alapuló kartell. A beszállítók dominanciája kedvezőtlen lehet a csatorna downstream tagjai számára, mert esetenként magasabb beszerzési költségekkel, nagyobb bizonytalansággal és az ellátás megjósolhatatlanságával kell számolniuk, így a downstream-szereplőknek magasabb biztonsági készleteket kell tartaniuk. Tipikusan beszállító által dominált iparág az olajipar.

3. Disztribútor-központú dominancia. Selldin és Olgaher (2007) szerint az agilis ellátási láncok jelentőségének elôtérbe kerülésével a disztribútorok (nagykereskedốk) csatornapozíciója erôsödött, hiszen döntő szerepük van a kiszállítások rugalmasságának biztosításában. A disztribútorok gyakorlatilag a kereskedôk „félmobil” raktáraként funkcionálnak. A visszutas logisztikában és a fenntartható (,zöld”) ellátási láncokban szintén meghatározó (esetenként domináns) szerepet tölthetnek be a jövốben. A késztermék-, valamint alkatrészgyártók részére végzett hulladékgyújjtés, bevizsgálás és újraelosztás, az újra nem hasznosítható hulladékoktól való megszabadulás, vagyis a teljes körú hulladékmenedzsment gyakran az ő feladatuk (Sangway, 2006).

4. (Kis)kereskedó-központú dominancia. Ez fóként az élelmiszeripar/napi fogyasztási cikkek láncaira jellemző. Az 1990-es évektől kezdődően a verseny egyre erősödő intenzitásával az olyan kereskedelmi láncok, mint a Wal-Mart, a Toys R Us, a McDonalds és a Home Depots gazdaságilag egyre inkább megerósödtek, domináns csatornatagokká váltak. Wang és Lui (2007), illetve Wang és Lau (2008) szerint a kereskedők ellátási láncbeli dominanciájának növekedése fốként annak köszönhetô, hogy ốk állnak a legközelebb a fogyasztókhoz, így könnyebben megérthetik 
azok igényeit és elvárásait. Csatornabeli pozíciójuknak köszönhetóen az ostorcsapás-effektus kedvezőtlen hatásai is a kiskereskedóket érintik a legkevésbé ${ }^{1}$. Emellett az információs hálózatok komplexitásának növekedése és fejlődése, illetve a globális elérhetôség megjelenése is elősegítette a többi lánctag feletti ellenőrzés gyakorlását. Govil és Proth (2002) szerint a kereskedốk domináns csatornataggá válásában döntô szerepet játszottak a globális fogyasztási cikkek, amelyek egyszerú kivitelezésúek, nagy tételben kerülnek előállításra, rövid átfutási időkkel és gyártási folyamatokkal, valamint erôs márkázással és logisztikával jellemezhetők. Choudhury et al. (2008) szerint a domináns kiskereskedelmi láncok sikerüket nagyrészt logisztikai és disztribúciós tevékenységük globális szintú ésszerúsítésének köszönhetik. Ezt párosítva az új, kifinomult technológiákkal jelentôs erófölényre tettek szert az upstream csatornatagok felett. Fontos információkat (pl. rendelési mennyiségek) szolgáltatnak az upstream tagoknak, így jelentôs függóség alakult ki az upstream szakasz vállalatai részéról.

Végezetül meg kell jegyeznünk, hogy egyes szerzók szerint a kulturális háttér is jelentős szerepet játszhat az ellátási láncbeli hatalmi viszonyok terén. Például Kínában a hatalmi egyenlótlenségek elfogadottak, az emberek elvárják, hogy a döntéseket a nagy hatalommal rendelkező szereplő́k hozzák meg, továbbá a lánctagok esetenként jobban hajlanak a jutalmazó és a kényszerítô hatalom láncbeli alkalmazására.

\section{Korábbi empirikus kutatások eredményei}

A vállalatközi kapcsolatokban kialakuló hatalom a legtöbb (Benton - Maloni, 2005; Caniels - Gelderman, 2007; Barber, 2011) szakirodalom szerint alapvetôen - a klasszikus vezetéstudományi csoportosítást követvén - öt forrásból származhat, amelyeket Belaya és Hanf (2009) az információs hatalommal egészített ki. A jutalmazó és a kényszerító hatalom közvetett, hiszen a hatalommal rendelkezô tag (például a vevô) által irányított, amely megjutalmazhatja a szállítót (például a rendelések növelésével), vagy hozhat olyan intézkedéseket, amelyek szállítóját hátrányosan érintik (például valamely termék rendelésének visszamondásával).

A vevő hatalmánál fogva eldöntheti, hogy alkalmazza-e hatalmát szállítója magatartásának befolyásolására, és ha igen, mikor és hogyan. A szakértói, a referens, a törvényes, valamint az információs hatalom közvetlen, mivel a szállító eldöntheti, hogy akar-e, illetve milyen mértékben akar a vevő befolyása alá kerülni. Ilyen esetekben a szállító együttmúködési lehetôséget keres a vevôvel például a vevő tudása vagy szakértelme (szakértôii hatalom), a birtokában lévő információk értéke (információs hatalom) vagy hírneve (referens hatalom) miatt.

A kapcsolódó szakirodalmakat elemezve kijelenthetjük, hogy az eltérő hatalmi viszonyok együttmúködésre gyakorolt hatását illetően igencsak megoszlik a kutatók véleménye. $\mathrm{Az} 1$. táblázat a témában végzett néhány fontosabb kutatási eredményt foglalja össze.

1. táblázat

Az eltérố hatalmi viszonyok és az együttmúködés kapcsolata

\begin{tabular}{|c|c|c|c|}
\hline \multirow[b]{2}{*}{ Szerző(k) } & \multicolumn{3}{|l|}{ Kutatási eredmény } \\
\hline & Pozitív kapcsolat & $\begin{array}{c}\text { Vizsgált ország és } \\
\text { iparág }\end{array}$ & $\begin{array}{c}\text { Vizsgált } \\
\text { kapcsolatok } \\
\text { (ellátási láncbeli } \\
\text { hely) }\end{array}$ \\
\hline $\begin{array}{l}\text { Brown et al. } \\
\quad(1995)\end{array}$ & $\begin{array}{l}\text { Olyan kereskedók és beszállítóik kapcsolatát vizsgálták, ahol a } \\
\text { beszállítók voltak erófölényben. Empirikus kutatásaik során igazolták, } \\
\text { hogy a közvetlen beszállítói hatalom gyakorlása egyrészt a kereskedő } \\
\text { partnerkapcsolat iránti elkötelezettségét, másrészt a beszállítók és a } \\
\text { kereskedők teljesítményének növekedését eredményezi. }\end{array}$ & $\begin{array}{l}\text { Egyesült Államok - } \\
\text { gépipar } \\
\text { (mezógazdasági } \\
\text { gépek) }\end{array}$ & $\begin{array}{l}\text { kereskedôk - } \\
\text { beszállítók }\end{array}$ \\
\hline $\begin{array}{c}\text { Kumar et al. } \\
\text { (1996) }\end{array}$ & $\begin{array}{l}\text { Pozitív kapcsolatot találtak a hatalmi aszimmetria és a partnerkapcsolat } \\
\text { iránti elkötelezettség között. Empirikus kutatásaik során } \\
\text { bebizonyították, hogy a függőségi aszimmetria növeli a kapcsolat iránti } \\
\text { elkötelezettséget és annak teljesítményét. }\end{array}$ & $\begin{array}{c}\text { Egyesült Királyság - } \\
\text { autóipar }\end{array}$ & $\begin{array}{l}\text { kereskedôk - } \\
\text { beszállítók }\end{array}$ \\
\hline $\begin{array}{l}\text { Maloni } \\
\text { és Benton } \\
(2000)\end{array}$ & $\begin{array}{l}\text { Arra az eredményre jutottak, hogy a közvetlen hatalom gyakorlása pozitív } \\
\text { hatással van az ellátási láncbeli partnerkapcsolatok szorosságára. Továbbá } \\
\text { megállapították, hogy a láncbeli dominancia eltéró mértéke szignifikáns, } \\
\text { pozitív hatással van az ellátási láncbeli teljesítményre (a domináns fél, az } \\
\text { alárendelt fél és a teljes ellátási lánc teljesítményére is). }\end{array}$ & $\begin{array}{c}\text { Egyesült Államok - } \\
\text { autóipar }\end{array}$ & $\begin{array}{l}\text { gyártók - } \\
\text { beszállítók }\end{array}$ \\
\hline
\end{tabular}




\begin{tabular}{|c|c|c|c|}
\hline $\begin{array}{l}\text { Goodman } \\
\text { és Dion } \\
(2001) \\
\end{array}$ & $\begin{array}{l}\text { Pozitív kapcsolatot tártak fel, amikor disztribútorok és gyártók } \\
\text { partnerkapcsolatát vizsgálták: a partnerek közötti hatalmi viszony a } \\
\text { kapcsolatba vetett elkötelezettség egyik legfontosabb tényezóje. }\end{array}$ & $\begin{array}{l}\text { Egyesült Államok - } \\
\text { több iparág }\end{array}$ & $\begin{array}{l}\text { gyártók - } \\
\text { disztribútorok }\end{array}$ \\
\hline $\begin{array}{l}\text { Huo et al. } \\
\text { (2005) }\end{array}$ & $\begin{array}{l}\text { Angol és ausztrál élelmiszer-ipari beszállító-gyártó partnerkapcsolatokat } \\
\text { vizsgáltak, és arra a következtetésre jutottak, hogy a beszállítók } \\
\text { közvetett és közvetlen hatalma pozitív hatással van a gyártók } \\
\text { együttmúköódés iránti elkötelezettségére. }\end{array}$ & $\begin{array}{l}\text { Anglia, Ausztrália - } \\
\text { élelmiszeripar }\end{array}$ & $\begin{array}{l}\text { gyártók - } \\
\text { beszállítók }\end{array}$ \\
\hline $\begin{array}{l}\text { Benton } \\
\text { és Maloni } \\
(2005)\end{array}$ & $\begin{array}{l}\text { Empirikus kutatásaik során bebizonyították, hogy egyenlötlen hatalmi } \\
\text { viszonyok esetén is előnyös lehet az együttmúködés az alárendelt fél } \\
\text { számára. A szállító-vevố kapcsolatokat vizsgálva megállapították, hogy } \\
\text { a hatalmilag kiegyensúlyozatlan együttmúködés pozitív hatással van } \\
\text { mindkét fél teljesítményére és elégedettségére. }\end{array}$ & $\begin{array}{l}\text { Egyesült Államok, } \\
\text { Japán - autóipar }\end{array}$ & $\begin{array}{l}\text { gyártók - } \\
\text { beszállítók }\end{array}$ \\
\hline $\begin{array}{l}\text { Hingley } \\
(2005)\end{array}$ & $\begin{array}{l}\text { Pozitív kapcsolatot talált az eltérő hatalmi viszonyok és az } \\
\text { együttmúködés között. Kutatásai során kimutatta, hogy a gyenge } \\
\text { hatalmi pozíciójú szállítók hajlanak az együttmúködésre a jelentôs } \\
\text { hatalommal rendelkezó vevókkel, mert így biztosítani tudják az } \\
\text { értékesítési mennyiséget. }\end{array}$ & $\begin{array}{l}\text { Egyesült Királyság - } \\
\text { élelmiszeripar }\end{array}$ & $\begin{array}{l}\text { kiskereskedók - } \\
\text { beszállítóik és vevőik }\end{array}$ \\
\hline $\begin{array}{l}\text { Belaya és } \\
\text { Hanf (2011) }\end{array}$ & $\begin{array}{l}\text { Empirikus kutatásaik szerint a jutalmazó, a szakértôi és az információs hatalom } \\
\text { alkalmazása pozitívan befolyásolja az ellátási lánc partnerkapcsolatait. }\end{array}$ & $\begin{array}{l}\text { Oroszország - élel- } \\
\text { miszeripar }\end{array}$ & $\begin{array}{l}\text { gyártók - kis- } \\
\text { és nagykereskedôk }\end{array}$ \\
\hline \multicolumn{2}{|r|}{ Negatív kapcsolat } & $\begin{array}{l}\text { Vizsgált ország és } \\
\text { iparág }\end{array}$ & $\begin{array}{l}\text { Vizsgált kapcsolatok } \\
\text { (ellátási láncbeli hely) }\end{array}$ \\
\hline $\begin{array}{l}\text { Skinner et al. } \\
\quad(1992)\end{array}$ & $\begin{array}{l}\text { Negatív kapcsolatot találtak a kényszerító hatalom alkalmazása és az } \\
\text { együttmúködések gyakorisága között. }\end{array}$ & $\begin{array}{l}\text { Egyesült } \\
\text { Államok, gépipar } \\
\text { (mezógazdasági és } \\
\text { energiaipari gépek) }\end{array}$ & $\begin{array}{l}\text { kereskedők - } \\
\text { beszállítók }\end{array}$ \\
\hline $\begin{array}{l}\text { Anderson és } \\
\text { Weitz (1992) }\end{array}$ & $\begin{array}{l}\text { Kutatásaik során megállapították, hogy a hatalmi egyenlőtlenségek } \\
\text { csökkentik a felek közötti bizalmat és elkötelezettséget. }\end{array}$ & $\begin{array}{c}\text { a tanulmányban nem } \\
\text { szerepel } \\
\end{array}$ & $\begin{array}{c}\text { gyártók - } \\
\text { disztribútorok }\end{array}$ \\
\hline $\begin{array}{l}\text { Kumar et al. } \\
\qquad(1995)\end{array}$ & $\begin{array}{l}\text { Vizsgálataik során arra az eredményre jutottak, hogy az eltérő } \\
\text { hatalmi viszonyok erósen negatív hatással vannak a bizalomra és az } \\
\text { együttmúködés iránti elkötelezettségre. A bizalom és az elkötelezettség } \\
\text { alacsony foka pedig kevésbé stabil, és alacsony hatékonyságú } \\
\text { partnerkapcsolatot eredményez. }\end{array}$ & $\begin{array}{l}\text { Egyesült Államok, } \\
\text { Latin-Amerika, } \\
\text { Ázsia, Európa - } \\
\text { élelmiszeripar, } \\
\text { autóipar, } \\
\text { telekommunikáció }\end{array}$ & $\begin{array}{l}\text { gyártók - } \\
\text { kereskedók }\end{array}$ \\
\hline $\begin{array}{l}\text { Maloni } \\
\text { és Benton } \\
(2000)\end{array}$ & $\begin{array}{l}\text { Vizsgálataikban kimutatták, hogy a közvetett hatalom alkalmazása } \\
\text { negatív hatással van a beszállító-vevô kapcsolatok szorosságára. }\end{array}$ & $\begin{array}{l}\text { Egyesült Államok, } \\
\text { autóipar }\end{array}$ & $\begin{array}{l}\text { gyártók - } \\
\text { beszállítók }\end{array}$ \\
\hline $\begin{array}{l}\text { Zhou et al. } \\
\text { (2007) }\end{array}$ & $\begin{array}{l}\text { Arra a következtetésre jutottak, hogy minél inkább eltérnek a } \\
\text { hatalmi viszonyok egy kapcsolatban, annál gyakrabban alakulnak ki } \\
\text { konfliktusok a tagok között. A partnerkapcsolat domináns tagja kevésbé } \\
\text { ragaszkodik a partner megtartásához, míg az alárendelt szerepló a } \\
\text { hatalommal való visszaélésre számítva agresszív stratégiát alkalmaz. }\end{array}$ & $\begin{array}{l}\text { Kína - } \\
\text { a tanulmányban } \\
\text { az iparági lehatárolás } \\
\text { nem szerepel }\end{array}$ & $\begin{array}{l}\text { kereskedők - } \\
\text { beszállítók }\end{array}$ \\
\hline $\begin{array}{l}\text { Caniels } \\
\text { és Gelderman } \\
(2007) \\
\end{array}$ & $\begin{array}{l}\text { Véleményük szerint minél nagyobb a tagok közötti erókülönbség, annál } \\
\text { gyakoribb a domináns tag részérôl a hatalommal való visszaélés, ami } \\
\text { hátrányosan befolyásolja az együttmúködés teljesítményét. }\end{array}$ & $\begin{array}{l}\text { Hollandia - } \\
\text { több iparág }\end{array}$ & $\begin{array}{l}\text { teljes beszállítói } \\
\text { hálózat }\end{array}$ \\
\hline $\begin{array}{l}\text { Belaya } \\
\text { és Hanf } \\
(2011)\end{array}$ & $\begin{array}{l}\text { Oroszországi élelmiszer-ipari beszállító-vevô kapcsolatokat vizsgálva } \\
\text { empirikus kutatásaik során arra a megállapításra jutottak, hogy a } \\
\text { kényszerító és a törvényes hatalom alkalmazása negatív hatással van az } \\
\text { ellátási hálózat együttmúködéseire. }\end{array}$ & $\begin{array}{l}\text { Oroszország - } \\
\text { élelmiszeripar }\end{array}$ & $\begin{array}{c}\text { gyártók - } \\
\text { kis- és nagykereske- } \\
\text { dók }\end{array}$ \\
\hline
\end{tabular}

A táblázatban szereplố empirikus kutatások közül több vizsgálat igazolta, hogy a hatalom egyes típusainak gyakorlása pozitív hatással van a partnerkapcsolatba vetett elkötelezettségre, illetve a vállalati teljesítményre. Ezen túl egyes kutatók pozitív kapcsolatot mutattak ki az erőfölény alkalmazása és a partnerkapcsolat sikere, valamint az ellátási láncbeli módszerek
Forrás: saját szerkesztés, 2013

alkalmazásának hatékonysága között. Az autóipar tökéletes példákat (lásd például a Toyota és a Honda ellátási lánca) szolgáltat arra, hogy egy domináns csatornatag hatalmi pozícióját kihasználva miként tud szorosan együttmúködni beszállítóval úgy, hogy a partnerkapcsolat kölcsönösen elônyös legyen, és valameny- 
nyi érintett lánctag teljesítménye növekedjen. A Honda beszállítóival kialakított szoros, partnerközpontú „Best Practice" stratégiájának köszönhetôen a beszállítók termelékenysége mintegy 50\%-kal, az általuk beszállított termékek minősége 30\%-kal növekedett, költségeik pedig 7\%-kal csökkentek (Liker - Choi, 2004).

A fentiekkel ellentétben azonban vannak olyan vizsgálatok, amelyek azt bizonyították, hogy bizonyos hatalomtípusok gyakorlása negatív hatással van a partner iránti bizalomra és elkötelezettségre. Más kutatások pedig azt igazolták, hogy a hatalmi dominancia gyakoribb konfliktusokhoz, visszaélésekhez vezet, negatív hatást gyakorol a kapcsolatok szorosságára és a hálózati együttmúködés eredményességére.

$\mathrm{Az}$ 1. táblázatban összegyuújtött kutatások hiányossága, hogy egyike sem foglalkozik a vállalatok méretével, illetve a méretból adódó, az eróviszonyokhoz kapcsolódó esetleges sajátosságokkal. Noha a láncbeli hatalom, illetve az együttmúködés és a vállalati teljesítmény viszonyát számos kutató vizsgálta, a kis- és középvállalkozások és a hatalmi viszonyok vizsgálatáról lényegesen kevesebb kutatás számol be. Harris et al. (2011) megállapították, hogy a partnertól való függőség mértéke meghatározó szerepet játszik a KKVszektorba tartozó beszállítók teljesítményében. Empirikus kutatásaik során bebizonyították, hogy a kis- és középvállalkozásoknál (a mikrovállalkozásokat leszámítva) pozitív kapcsolat áll fenn a beszállítók vevőtól való függőségének mértéke és teljesítménye között. McDowell et al. (2010) kis- és középvállalkozások és domináns vevôik kapcsolatát vizsgálták. A KKV-kat két csoportra osztották (mikrovállalkozások, illetve kis- és középvállalkozások). Empirikus kutatásaikkal ók is azt igazolták, hogy a mikrovállalkozások esetében sokkal inkább jellemző állításuk, miszerint ha erôsebb a partnertôl való függóség, növekszik a vállalati teljesítmény. Ez tulajdonképpen nem meglepó, hiszen a nagyobb méretú KKV-k könnyebben tudnak hozzájutni azokhoz az erôforrásokhoz és technológiákhoz, amelyek az információfeldolgozáshoz és -továbbításhoz, valamint múködésük javításához szükségesek. A mikroméretú beszállítók sokkal inkább rászorulnak partnereikre, aminek következtében szorosabb kapcsolatot alakítanak ki velük. Ennek következménye, hogy e beszállítók erôteljesen függnek egyetlen vagy néhány vevôtőll, amíg a közepes méretú beszállítók lényegesen kiterjedtebb és változatosabb vevői körrel rendelkeznek.

Az elmúlt időszak nemzetközi kutatásai szerint a dominancia-aszimmetria az alárendelt partnernél járhat negatív következményekkel, de járhat pozitívokkal is, ami az alárendelt partner és/vagy a többi lánctag teljesítményét is növelheti.

\section{A domináns csatornatagok hatása az élelmiszer- ipari ellátási láncok múködésére}

Az FMCG/Food szektorban az elmúlt évtizedben a kiskereskedelmi láncok szerepének és arányának növekedése, illetve a kiegészítő és a helyi ellátási láncok szerepének visszaszorulása volt tapasztalható. Smith et al. (2010) az élelmiszer-ipari ellátási láncokban a döntéshozói hatalom alapján három korszakot különböztet meg:

1) 1870-es évek - II. világháború az alapanyag-termelók voltak a döntéshozók, a fogyasztóknak minimális befolyása volt a termelésre,

2) 1950-es évek - 1990-es évek: a feldolgozóipar vállalatai kerültek erófölénybe,

3) 1990-es évektől napjainkig: a kiskereskedelmi láncok dominanciája tapasztalható a megnövekedett fogyasztói elvárások (minőség, biztonság, etikai kérdések) mellett.

A szektor vállalatainak méret szerinti megoszlása sajátos képet mutat, hiszen a kis- és a közepes méretú vállalkozások aránya magas, ugyanakkor piaci részesedésük nem számottevố. A piaci volumen jelentôs része néhány nagy üzletlánchoz kapcsolható, s jellemző e kiskereskedelmi üzlethálózatok dominanciája a beszállítókkal szemben. Ezt jól példázza, hogy számukra nagyon kedvező, a szállítástól számított 30-90 napos fizetési halasztást kérnek (és kapnak) a beszállítóiktól. A szektorban múködő ellátási lánctagok tevékenységét jelentősen befolyásolják a domináns csatornatagok (a ,nagy kiskereskedelmi láncok"). Ezek a beszállítói és vevői oldalt is befolyásolni tudják, aminek következtében a szektor marketing- és logisztikai tevékenysége e „rendszerintegrátorok" által központosított. A domináns csatornatagok piaci ereje nemcsak hazánkban, hanem egész Európában és globálisan is jellemző: a kontinens élelmiszer-kereskedelmében a legnagyobb forgalmat lebonyolító vállalkozás az amerikai Wal-Mart, majd azt követi a francia Carrefour+Promodes és a Tesco. A három vállalatcsoport együttes forgalma meghaladja a szektor összes forgalmának 35 százalékát (Pénzes, 2009).

Napjainkra az idó, gazdasági jelentőségének felértékelődése miatt, gyakorlatilag szúkösebb erőforrássá vált, mint a vállalatok rendelkezésére álló tốke. Ennek következtében egyes piacokon az időérzékenység átvette a korábban jellemző árérzékenység (üzleti tranzakciókban betöltött) domináns szerepét (Földesi et al., 2011). Az FMCG/Food szektorban az időalapú verseny hatásai erôteljesen érezhetốk, melynek eredményeként ma már ,nem a nagyobb (v)eszi meg a kisebbet, hanem a gyorsabb a lassabbat". Óriási a verseny a szektorban múködő ellátási láncok között is (pl. Tesco, Auchan, Cora stb.), melyet ezek a nagy multinacionális vállala- 
tok egymással folytatnak (Szegedi, 2008). Esetenként ez a verseny már túlzottan is gyors, aminek következménye, hogy a végső fogyasztó még mindig nem képes befolyásolni a láncot. Dominanciájuknak köszönhetôen a kiskereskedelmi láncok határozzák meg, hogy:

- upstream oldalról mi kerüljön be a csatornába, befolyást gyakorolnak a gyártásra, a minôségre, a múszaki fejlesztésre stb., és nemzetközi beszerzéseik révén a globális verseny valósul meg,

- downstream oldalon ók elégítik ki, de emellett módosítják is a vásárlói igényeket, sőt: esetenként új igényeket is teremtenek (Szegedi, 2012).

A szektor további sajátossága a termelók és a kereskedók közötti gyakori konfliktusok jelenléte. A láncon belüli erôviszonyok következtében még a szállítási költségérzékeny magyar termékek (fôleg az agrártermékek, pl. tej, dinnye stb.) is erôs nemzetközi konkurenciát kapnak, amely elsősorban a hazai kis- és középbeszállítókat érinti hátrányosan. A szektor lényeges jellemzője a kereskedók saját márkáinak jelenléte (Spar, Tesco stb. termékek), amelyek a jellemzően árérzékeny fogyasztóknak köszönhetően jelentős piaci részesedéssel bírnak ma már. Mielőtt a Spar Csoport bevezette saját márkáját, az üdítőital-értékesítés 90\%át Coca-Cola- és Pepsi-termékek tették ki. Három hónappal a bevezetést követóen a saját márkás üdítőitalok a forgalom 60\%-át adták (Schubert, 2007).

A domináns kiskereskedelmi láncok jelenlétének számos - a folyamat egészére kiható - előnye is van. A végső fogyasztó szempontjából kedvező, hogy beszállítói oldalon lenyomják az árat, így olcsóbban adhatják a termékeiket az output oldalon. Továbbá kutatás- és innovációbefolyásoló szereppel bírnak, illetve fontos szerepet játszanak a láncok koordinálásában. Piackutatást végeznek, tesztelik a piacot, melynek eredményeként olyan termékeket vásárolnak meg beszállítóiktól, amelyet aztán értékesíteni is tudnak: ezáltal egyfajta termelésbefejezô szereppel bírnak. Logisztikai szempontból pedig folyamatfelgyorsító szerepet töltenek be. Mérik a logisztikai folyamataikat azért, hogy gyorsítani tudják készleteik forgási sebességét, ezáltal csökkenteni, vagy akár teljesen kiküszöbölni a raktározási tevékenységüket (pl. a Cross-Docking alkalmazásával).

A domináns kiskereskedók jelenléte információs aszimmetriát okoz a szektor ellátási láncaiban. Ez a jelenség természetesen szoros kapcsolatban áll az ellátási lánc egyes szintjein tapasztalható koncentráció mértékével is. Amíg a szektor ellátási láncainak upstream oldalán több ezer beszállítóval találkozhatunk (amelyek nehezen jutnak információhoz), addig a kiskereskedelmi láncok száma (beleértve az egyuittmúködések eredményeként megalakult beszerzési társulásokat) hazánkban mindössze egy tucatnyi. Ennek következménye, hogy a kereskedók számára a partnerváltás költsége alacsony, miközben a beszállítók csak nagyon nehezen és jelentős költségek mellett válthat(ná)nak partnert, hiszen egy-egy vevőjük elvesztése forgalmuk jelentős visszaesését eredményezné. (Meg kell azonban jegyezni, hogy a koncentráció mértéke eltérô a szektoron belüli iparágak esetében: a tejiparban erôteljes koncentráció tapasztalható, a húsiparban viszont lényegesen alacsonyabb a koncentráció mértéke.)

Emellett erôfölényüknek köszönhetően különböző eróforrás-igényes elvárásokat támasztanak beszállítóikkal szemben. Ilyen például a lánc információs rendszeréhez való kapcsolódás követelménye - néhány lánc ma már beszállítói alapkövetelményként írja eló, hogy beszállítói RFID tag-eket helyezzenek el a beszállított termékeiken vagy egységrakományaikon.

\section{A kutatás módszertana}

Vizsgálatunk elsô lépéseként tanulmányoztuk a korábban, hasonló témában végzett nemzetközi kutatások eredményeit, amelyek tapasztalatait felhasználva állítottuk össze a felmérésünk alapjául szolgáló kérdőívet, amelyból a késóbbi statisztikai vizsgálatok primer adatforrásai származnak. A kérdőívet elsóként egy kérdőíves lekérdezésekben jártas szakemberrel, két németországi egyetemi professzorral, valamint két hazai vállalatvezetővel töltettuik ki. Tapasztalataik és véleményeik alapján néhány módosítást hajtottunk végre annak érdekében, hogy a vizsgált célcsoport számára valamennyi kérdés könnyen értelmezhető és viszonylag rövid idő alatt megválaszolható legyen. Jelen tanulmány a kutatás során alkalmazott kérdőívnek csak a témába vágó kérdéseit dolgozza fel.

Ezt követóen meghatároztuk a vizsgálatban részt vevő vállalatok körét, az alapsokaságot. Az alapsokaságba azokat a kis- és középvállalatokat soroltuk, amelyek az FMCG/Food szektorban az élelmiszerek, italok és dohánytermékek gyártásával, kis- és nagykereskedelmével foglalkoznak. A hazai FMCG/Food szektorban 2009-ben mintegy 93.000 vállalat tevékenykedett. Ezek tevékenységek szerinti megoszlását a 2. táblázat szemlélteti.

A 2. táblázatban valamennyi méretkategóriába tartozó vállalat szerepel (beleértve a mikro- és a nagyvállalatokat is, amely kategóriákra vizsgálatunk nem terjed ki). Arról nem áll rendelkezésre információ, hogy mekkora az FMCG/Food szektorban múködő kis- és középvállalkozások száma. A saját kezúleg összeállított adatbázisban valamivel több mint 600 szektorbeli kis- és középvállalat szerepelt. Ezek közül mintegy 550 vállalatnak 
sikerült eljuttatnunk a kérdőívet. A kérdőívek egy kisebb részének lekérdezése egy on-line felületen történt, ahol a vállalatvezetók egy általunk megadott jelszó segítségével történố belépés után adhatták meg válaszaikat. A kérdőívek döntô többsége személyes lekérdezés formájában került kitöltésre. A kérdőívet a vállalatok egyegy stratégiai vezetője (döntő többségében logisztikai vezetôk és ügyvezetố igazgatók) töltötte ki.

A visszaérkezett mintegy 450 kitöltött kérdőívet megszürtük, aminek eredményeként 196 kérdőívet találtunk kielemezhetőnek. A többi kérdőív a következő okok miatt nem kerülhetett be a vizsgálatba:

- az adott vállalat az előzetes információink ellenére nem tartozott bele az alapsokaságba vagy az eltérô méretkategória, vagy az eltérố tevékenységi szektor miatt,

- a kérdőív kitöltése annyira hiányos volt, hogy ez meggátolta annak feldolgozhatóságát, és így néhány esetben elófordult például, hogy a vállalat nem adta meg a nevét, aminek hiányában nem volt lehetőségünk hozzájutni a vizsgálathoz szükséges teljesítménymutatók alapját képező adatokhoz,

- a kérdőívben szereplő kontrollváltozók nagyon ellentmondásos képet mutattak, ami megkérdőjelezte a kérdőívben szereplő információk hitelességét, valósságát,

- néhány esetben a kérdőíven nem szerepelt a kitöltô személy aláírása, valamint a vállalat pecsétje, amely szintén a fenti problémát vetette fel.

A tanulmány elemzési részének alapját képezô adatbázis összeállításához szekunder adatokat gyújtöttünk, amelyek felhasználásával teljesítménymutatókat számoltunk a kiválasztott 196 vállalatra vonatkozóan. Az alkalmazott jövedelmezóségi mutatók számításához szükségünk volt a vállalatok adózott eredményé-
2. táblázat

Az FMCG/Food szektor vállalatainak száma tevékenységek szerint (2009)

\begin{tabular}{|l|c|}
\multicolumn{1}{|c|}{ Tevékenységi kör } & $\begin{array}{c}\text { Vállalatok } \\
\text { száma (db) }\end{array}$ \\
\hline 10: Élelmiszergyártás & 3525 \\
\hline 11: Italgyártás & 1477 \\
\hline 12: Dohánytermék gyártása & 4 \\
\hline 463: Élelmiszer-, ital-, dohányáru nagykereskedelme & 37541 \\
\hline 472: Élelmiszer-, ital-, dohányáru kiskereskedelme & 50592 \\
\hline Összesen & $\mathbf{9 3 1 3 9}$ \\
\hline
\end{tabular}

Forrás: saját gyújtés, 2012

re, saját tő́kéjének értékére, valamint összes eszközeinek értékére. Ezen adatokat a vállalatok mérlegéból és eredménykimutatásából gyújtöttük ki, amelyeket a Közigazgatási és Igazságügyi Minisztérium elektronikus beszámoló portálján értünk el. A fenti információk felhasználásával az alábbi jövedelmezôségi mutatókat számoltuk ki valamennyi vállalatra (196) vonatkozóan, amelyeket a következóképpen értelmeztünk:

- sajáttóke-arányos nyereség (ROE): az adózott eredmény és a saját tóke hányadosa, amely a befektetett saját vagyon tiszta hozamát fejezi ki,

- eszközarányos nyereség (ROA): az adózott eredmény és az összes eszköz hányadosa. A mutató a vállalkozás múködésének jóságát fejezi ki, függetlenül annak finanszírozási forrásától.

A kérdőívek lekérdezése 2011-ben zajlott le, ennek megfelelően a teljesítménymutatók számításához felhasznált adatok is a vállalatok 2011. évi éves beszámolójából származnak. A vizsgálatunk alapjául szolgáló adatbázis összeállításának lépéseit az 1 . ábra szemlélteti.

\section{A vizsgálati adatbázis kialakításának lépései}

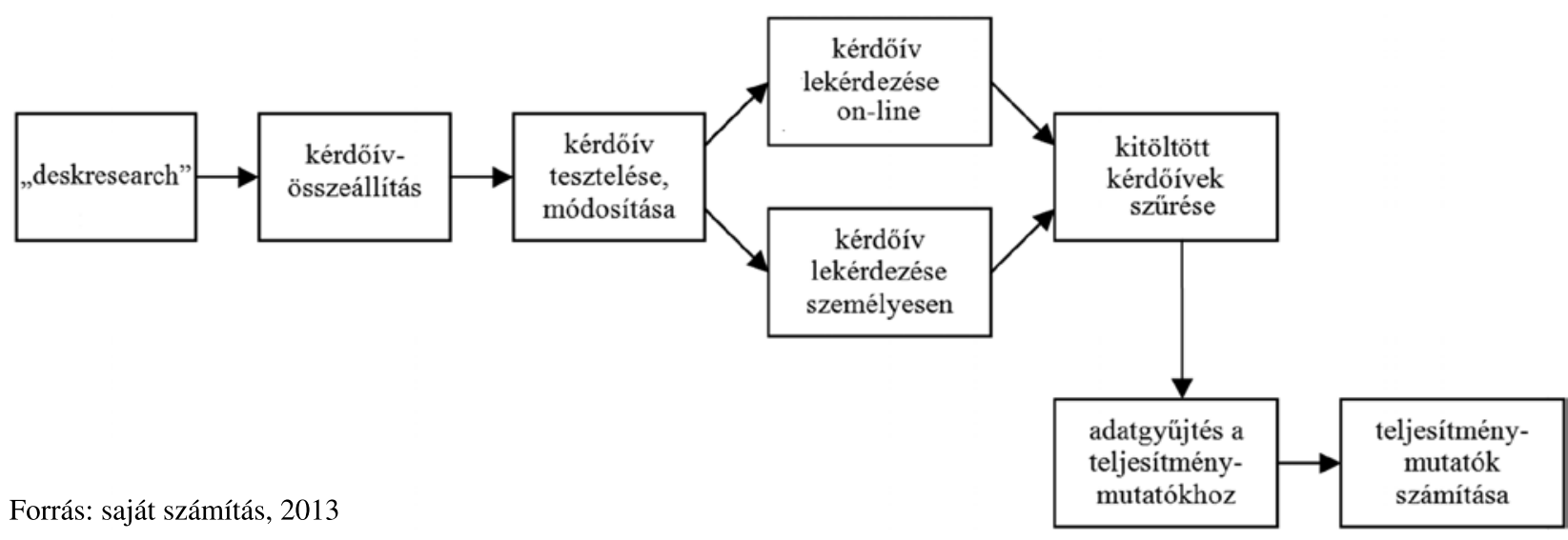


A kérdőívet kitöltő vállalatok egyharmada a kisvállalati, kétharmada a középvállalati méretkategóriába tartozik. A mintában szereplő KKV-k méretkategória és tevékenységek szerinti megoszlását a 3 . táblázat szemlélteti. A vállalatok közel fele élelmiszergyártással foglalkozik, a minta egynegyedét pedig a kiskereskedôk teszik ki. nyi ellátási láncbeli partnerkapcsolatukat) rangsorolják az erőviszonyok alapján vevőiket, a saját vállalatukat és beszállítóikat. (Az egyes ábrákhoz tartozó kérdőívbeli kérdéseket a mellékletek tartalmazzák, amelyekre az ábrák elnevezése mellett hivatkozunk.) Az 1. ábra megerősíti azt a feltételezést, hogy a KKV-szektor tagjai viszonylag alacsony hatalommal rendelkeznek: a

\section{3. táblázat} vállalatok többsége (111 vállalat) azt válaszolta, hogy dominánsabbak ugyan beszállítóiknál, de erôteljesen függnek vevőiktól, feltételezhetôen a kiskereskedelmi láncoktól. Valószínúsíthetô, hogy a vizsgált vállalatok beszállítói szintén kis- és középvállalkozások, amelyek a vizsgálatban résztvevốk közül a leggyengébb hatalmi pozícióval rendelkeznek. Noha a Forrás: saját szerkesztés, 2013

A minta kialakításához rétegzett mintavételt alkalmaztunk (ahol a két réteget a két vállalati méretkategória jelentette), öszszetételét vizsgálataink elvégzéséhez alkalmasnak tekintjük, ugyanis a kis- és középvállalatok mintabeli megoszlása lehetővé teszi a méretkategóriák közötti öszszehasonlítást, továbbá az ellátási láncok egyes szintjein elhelyezkedó vállalatok (gyártók, kis- és nagykereskedốk) megfelelố számban reprezentáltak a mintában.

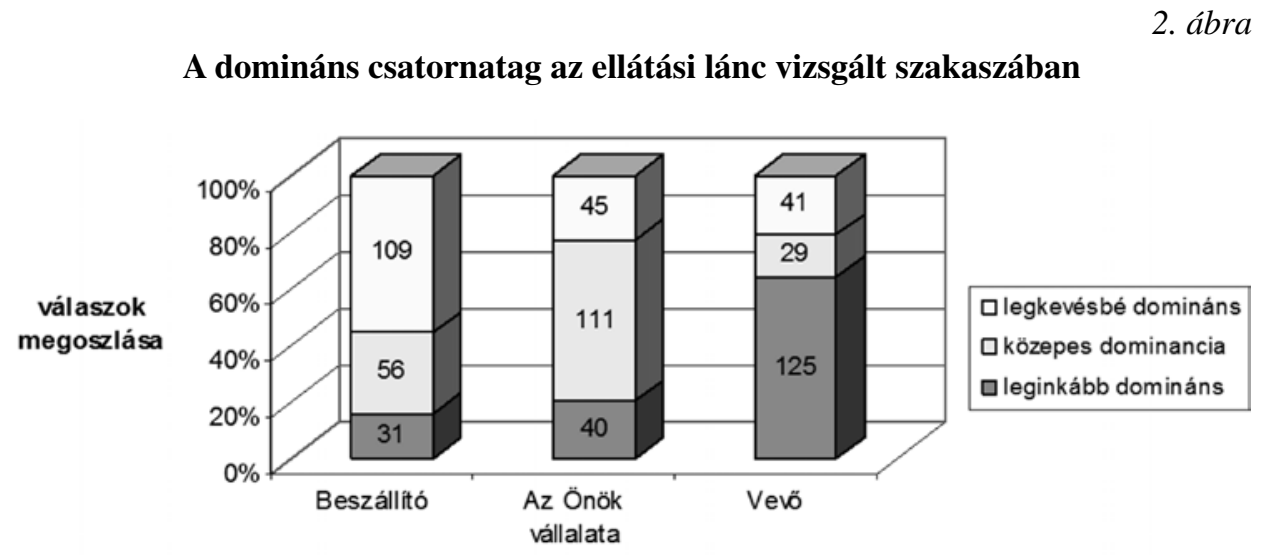

Forrás: saját számítás, 2013

\section{Eredmények}

Ahogyan a „Szakirodalmi áttekintés” címú fejezetben említettük, a domináns csatornatagok (kiskereskedelmi láncok) meghatározó szerepet töltenek be az FMCGtermékek piacán. Kérdőívünkben arra kértük a vállalatokat, hogy összességében (figyelembe véve valameny-
Vizsgálatunkba második dimenziónak bevontuk a tevékenységi szektort, így a fent kapott eredményeket két dimenzióban ábrázoltuk (3. ábra). Az ábra alatti elsố számsor a hatalmi pozíciót (1: leginkább domináns, 2: közepes dominancia, 3: legkevésbé domináns), míg a második számsor a tevékenységi szektort, azaz az ellátási lánc egyes szintjeit (10: Élelmiszergyár- 
tás, 11: Italgyártás, 463: Élelmiszer-, ital-, dohányáru nagykereskedelme, 472: Élelmiszer-, ital-, dohányáru kiskereskedelme) azonosítja. Az ellátási láncok egyes szintjein, egyetlen kivétellel, az előző ábra segítségével bemutatott eredmények köszönnek vissza, vagyis az egyes tevékenységi szektorokban a vizsgált vállalatok vevôi a leginkább dominánsak, míg beszállítóik a legkevésbé. A kiskereskedők szintjén azonban jellemzően maguk a megkérdezett vállalatok töltik be a leginkább domináns szerepet. Ez megerôsíti a korábbi megállapításunkat, hogy a gyártóktól a kiskereskedốkig terjedô láncszakaszokban a hatalmi pozíció növekszik a tevékenységi szektortól, azaz a láncbeli pozíciótól függően. A hatalmi viszonyoknak az inverz ellátási lánc mentén történő gyengülése többek között a visszafelé áramló keresleti információk csökkenő mennyiségére és minőségére vezetô vissza.

A domináns csatornatag az egyes tevékenységi szektorok függvényében (1. melléklet, 1. kérdés)

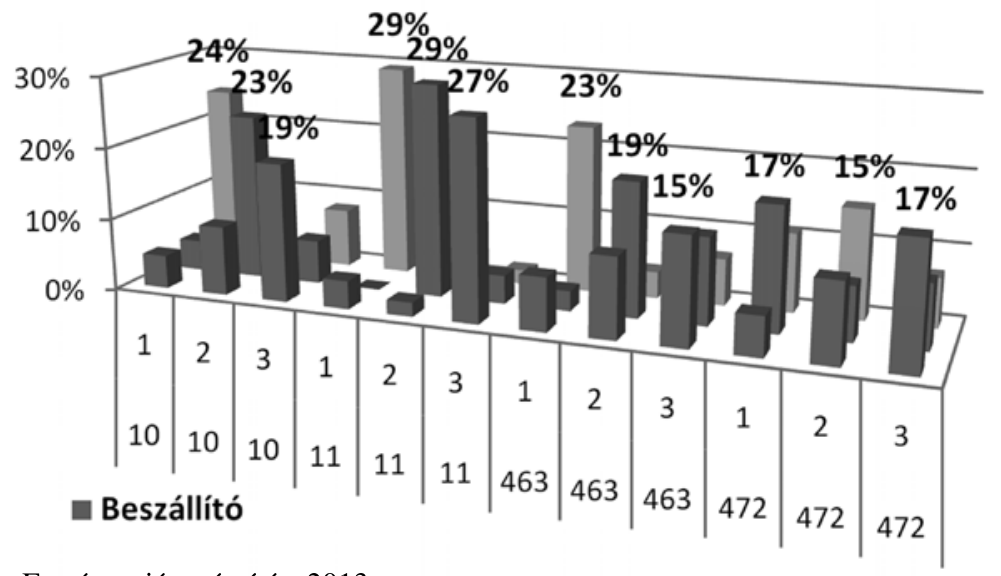

Forrás: saját számítás, 2013

A hatalmi viszonyok ellátási láncbeli partnerkapcsolatokban betöltött növekvô szerepe felveti a kérdést, hogy miként nyilvánul meg a dominancia a partnerkapcsolatokban. Kutatási eredményeink szerint alapvetően a domináns csatornatagok határozzák meg az árakat és a szállítási feltételeket (pl. szállítási határidő, mennyiség stb.), ami jelentôs hatást gyako- rol többek között a lánctagok készletgazdálkodására, így a láncban adott időpontban jelentkező készletszintekre is. Ez megegyezik Mukhtar és Shaharoun (2002) véleményével, miszerint a domináns csatornatagok hatalmuk gyakorlásával jelentôs befolyást gyakorolnak az árakra és a lánctagok készletgazdálkodására. A válaszadók több mint $40 \%$-a szerint a domináns tagok döntô szerepet játszanak a fizetési feltételek (pl. fizetési határidő) megszabásában is. A vállalatok a megadott válaszok mellett egyéb, saját tényezóket is megadhattak, ahol leggyakrabban a minőséget, a szolgáltatási színvonalat és a termékválasztékot említették, mint a domináns tag részéról fennálló elvárást.

A két méretkategória vállalatainak válaszait a 4. ábra szemlélteti. A középvállalatok „bátrabban” jelölték meg az egyes válaszokat, így valamennyi válaszlehetőségnél magasabb arányokat tapasztalunk. Ugyanakkor

3. ábra a hatalom egyes megnyilvánulási formáinak egymáshoz viszonyított gyakorisága hasonló a két méretkategória esetében.

Ha ismételten megvizsgáljuk a kapott válaszokat a tevékenységi szektorok függvényében (5. ábra), akkor azt tapasztaljuk, hogy az ellátási lánc valamennyi szintjén mind a kis-, mind a középvállalatok elsődlegesen az ár, másodlagosan a szállítási feltételek, majd a fizetési feltételek meghatározását jelölték meg, mint a domináns csatornatagok részéról fennálló legfontosabb elvárásokat. Ez gyakorlatilag azt jelenti, hogy a láncban fizikailag elfoglalt hely nem befolyásolja a láncbeli dominancia megnyilvánulási formáit.

Arra is kértük a vizsgálatban részt vevô vállalatokat, hogy partnerkapcsolataik száza-

4. ábra
Az ellátási láncbeli dominancia megnyilvánulási formái a vállalati méretkategória függvényében (1. melléklet, 2. kérdés)

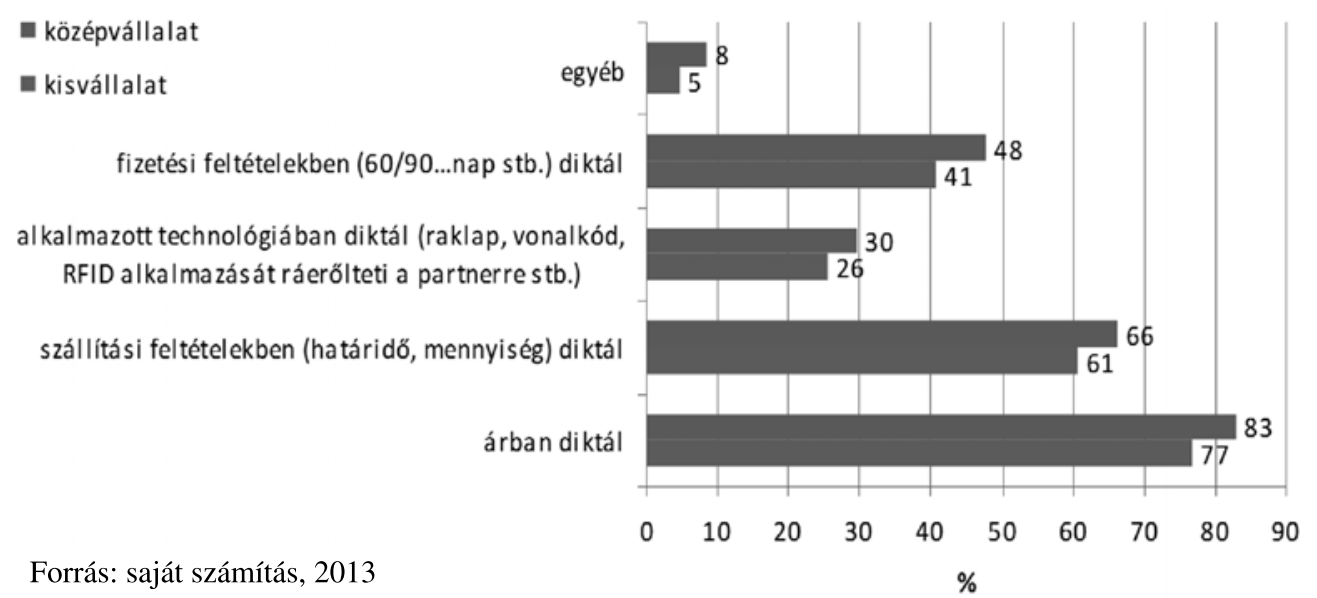


5. ábra kutatások igen ellentAz ellátási láncbeli dominancia megnyilvánulási formái a vállalati méretkategória és a tevékenységi szektor függvényében (1. melléklet, 2. kérdés)

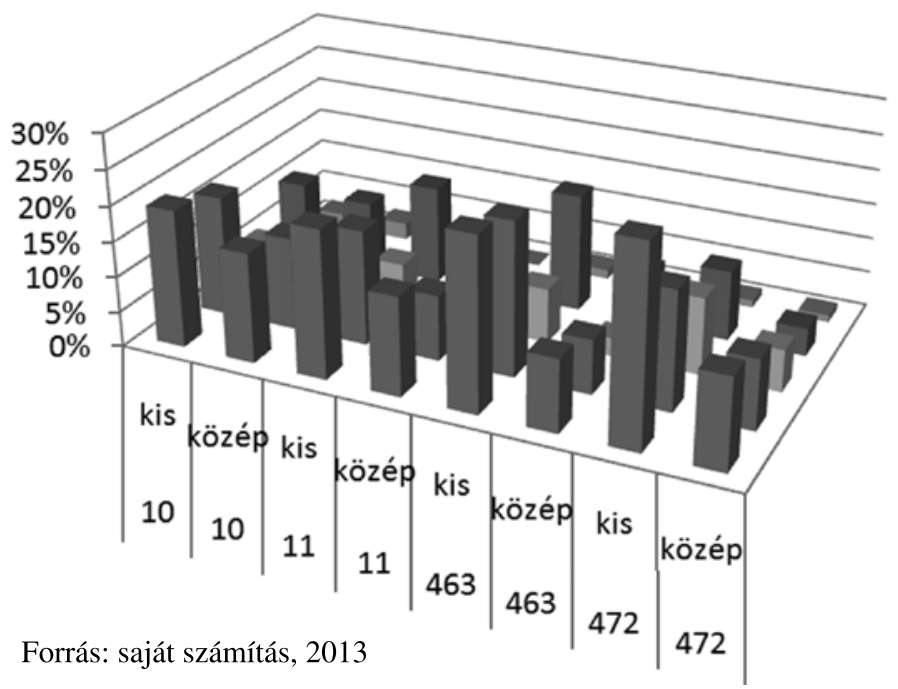

lékában adják meg, hogy (a partnerkapcsolatokat egyenként vizsgálva, függetlenül attól, hogy beszállítói vagy vevői kapcsolatról van szó) a kapcsolatok hány százalékában tartják magukat dominánsnak, a partnerrel egyenrangúnak, illetve alárendeltnek. A vállalatok átlagosan partnerkapcsolataik mintegy egynegyedében (26\%) érezték magukat alárendeltnek, 31\%-ában dominánsnak és $43 \%$-ában egyenrangúnak. Az alárendelt viszonyok közé fóként a vevôi kapcsolataik, domináns kapcsolataik közé pedig valószínúsíthetően a beszállítói kapcsolataik többsége tartozik. A 6. ábra e vizsgálat kisvállalatok és középvállalatok közötti különbségét szemlélteti. Lényeges különbség nem tapasztalható a két méretkategória között, amely némileg meglepó, mivel elózetes feltételezéseink alapján azt vártuk volna, hogy a középvállalatok nagyobb arányban értékelik magukat dominánsnak, és kisebb arányban alárendeltnek, mint a kisvállalatok.

Ahogyan a szakirodalmi áttekintés során bemutattuk, a korábban más kutatók által elvégzett empirikus

Az egyes partnerkapcsolatokban betöltött hatalmi szerep megítélése

(1. melléklet, 3. kérdés)

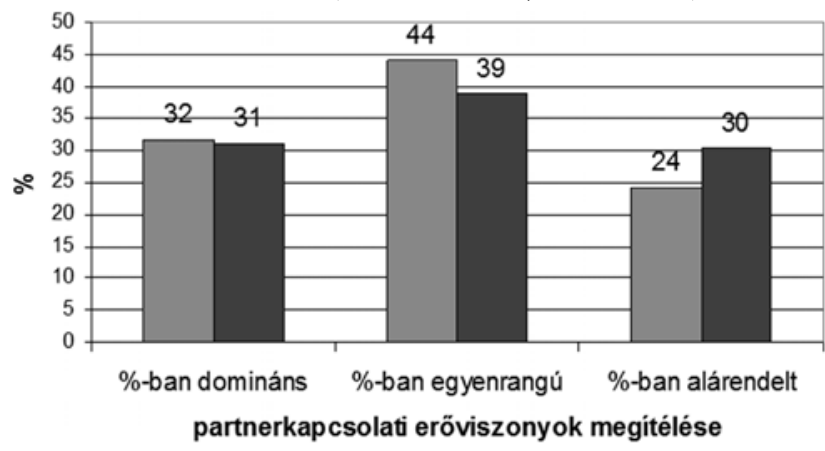

nárban diktál

— szállítási feltételekben (határidő, mennyiség) diktál

च alkalmazott technológiában diktál (raklap, vonalkód, RFID alkalmazását ráerőlteti a partnerre stb.) mondásos eredményekkel szolgálnak a hatalmi viszonyok, illetve a partnerkapcsolat eredményessége és a vállalati teljesítmény kapcsolatában. Saját kutatásunk fontos célja volt feltárni azt is, hogy a magyarországi élelmiszeripari KKV-k esetében a hatalmi viszonyok befolyásolják-e (ha igen, akkor hogyan) a vállalatok jövedelmezőségét és egyéb ellátási láncbeli sajátosságait.

$\mathrm{Az}$ 5. ábránál ismertetett kérdésre kapott válaszok alapján osztályoztuk a vállalatokat aszerint, hogy jellemzóen milyen hatalmi szerepet töltenek be partnerkapcsolataikban:

1) alárendelt vállalatok: azok, amelyek partnerkapcsolataik több mint felében ellátási láncbeli partnereiktól függenek,

2) domináns vállalatok: kapcsolataik több mint 50 százalékában dominánsak,

3) kiegyensúlyozott hatalmi viszonyokkal jellemezhetố vállalatok: amelyek partnerkapcsolati eróviszonyai viszonylag egyenletesen oszlanak meg a három kategória között (vagyis az előző két kategóriába nem besorolhatók).

Elsôként arra voltunk kíváncsiak, hogy a partnerkapcsolatokban általában betöltött hatalmi szerep befolyásolja-e a vállalatok olyan ellátási láncbeli sajátosságait, amelyeket csak nehezen lehet számszerúsíteni, így a partnerkapcsolat szorosságát beszállítói, illetve

6. ábra

(in
szállítói és vevôii oldalon, a vállalat stratégiai helyzetének megítélését, az információmegosztási hajlandóságot, a beszállítói, illetve a vevői kapcsolatok tartósságát. A kérdés megválaszolásához kereszttábla-elemzést végeztünk. A 2. melléklet a vállalatok hatalmi pozíciója és a fent ismertetett változók közötti feltételezett összefüggések vizsgálatának eredményeit szemlélteti (a szignifikanciaszintet három mutató kiszámolásával ellenőriztük). Öt változó esetében a vizsgálatban szereplő

Forrás: saját számítás, 2013 
vállalatoknál nem tapasztalható szignifikáns kapcsolat a hatalmi pozícióval, vagyis többek között nem találtunk kapcsolatot az eltérố erôviszonyok és a bizalom foka között, sem beszállítói, sem vevői oldalon, azaz a vizsgált KKV-k esetében a hatalmi függóség nem befolyásolja a partnerbe vetett bizalom mértékét. Ugyanakkor emlékeztetünk arra, hogy Anderson és Weitz (1992), illetve Kumar et al. (1995) negatív kapcsolatot tárt fel a hatalmi egyenlőtlenségek és a bizalom mértéke között (lásd 1 . táblázat).

Mivel három változó a) a kapcsolat szorossága vevôi oldalon, b) a vevôi és c) a beszállítói kapcsolatok tartóssága) esetében azt feltételezhetjük, hogy szignifikáns összefüggés áll fenn, ezért célszerú megvizsgálni azok erősségét, illetve irányát. A kapcsolat erősségének és irányának megállapítására a Kendall's tau-c, a Gamma és a Somers-féle $d$ mutatókat (a változók mérésénél alkalmazott ordinális skáláknak megfelelően) számoltuk ki, amelyek értékei alapján a következô megállapításokat tettük:

- A partnertól való függés mértéke és a vevookkel kialakított kapcsolat szorossága között negatív, viszonylag gyenge, de szignifikáns kapcsolat áll fenn. Vagyis azok a vállalatok, amelyek jellemzően alárendeltnek ítélik meg az ellátási láncbeli partnerkapcsolataikban betöltött szerepüket, szorosabb kapcsolatot alakítanak ki vevôikkel (amely vélhetően egyfajta kényszer egyrészt a domináns tag elvárásainak való megfelelés következtében, másrészt a sikeres múködés, a fennmaradás ezt követeli meg e vállalatoktól). A dominánsabb vállalatok viszont vevőik irányába lazább partnerkapcsolatokkal jellemezhetók. Itt visszautalunk Maloni és Benton (2000) empirikus kutatási eredményeire, melyek szerint a közvetlen hatalom gyakorlása pozitív hatással van az ellátási láncbeli kapcsolatok szorosságára, míg a közvetett hatalom alkalmazása negatívan befolyásolja a partnerkapcsolatok szorosságát (lásd 1. táblázat). A szerzőpáros azonban nem tett különbséget az upstream és a downstream partnerek között, ellentétben velünk. Vizsgálataink során beszállítói oldalon nem találtuk összefüggést az erőfölény alkalmazása és az együttmúködések szorossága között, míg vevôii oldalon szignifikáns kapcsolat áll fenn a két vizsgált tényező között.

- Az 1. táblázatban ellentmondásos kutatási eredményeket olvashatunk a dominancia partnerkapcsolat iránti elkötelezettségre gyakorolt hatásáról is. Egyes szerzók szerint pozitív, míg mások szerint negatív kapcsolat áll fenn a partnertól való függőség és a kapcsolat iránti elkötelezettség, a kapcsolat tartóssága között. Vizsgálatunk újszerúsége többek között abban áll, hogy a vizsgált vállalatok partnerhez viszonyított hatalmi pozícióját külön-külön elemeztük vevôi, illetve beszállítói oldalon a méretkategória függvényében. A beszállítókkal kialakított kapcsolatok tartóssága és a hatalmi pozíció között szignifikáns, közepes erôsségú, pozitív irányú kapcsolat van. Ez azt jelenti, hogy a dominánsabb vállalatok beszállítóikkal alapvetốen tartós, hosszabb távú együttmúködéseket alakítanak ki, míg az alacsony hatalmi pozícióval rendelkező vállalatok beszállítói kapcsolataikban elsősorban rövid távú partnerkapcsolatokkal jellemezhetók. A vevői oldalon viszont ennek az ellenkezője tapasztalható, hiszen a két változó közötti kapcsolat a közepesnél valamivel gyengébb, negatív irányú. A partnerkapcsolataikban alapvetően alárendelt szerepet betöltő vállalatok jellemzően hosszabb távú kapcsolatokra törekednek vevóikkel (ez összhangban áll a korábban ismertetett összefüggéssel, miszerint a gyengébb hatalmi pozíciójú vállalatok szorosabb vevői kapcsolatokkal jellemezhetôk), míg a dominánsabb vállalatoknál kevésbé jellemzőek a hosszabb távú vevôi kapcsolatok.

A nehezen számszerűsíthető tényezók elemzését követôen megvizsgáltuk a partnerkapcsolatokra jellemző erôviszonyok és a könnyebben számszerúsíthetô tényezôk (jövedelmezôség, ellátási láncbeli módszerek alkalmazási gyakorisága) kapcsolatát. Az ellátási láncbeli módszerek (VMI, késleltetés, EDI) alkalmazási gyakoriságát vevôi és beszállítói oldalon is vizsgáltuk. A jövedelmezôségi mutatóknál tapasztaltunk néhány extrém, illetve negatív értéket, amelyeket kizárva 164 vállalat maradt a vizsgálatban. Az ellátási láncbeli módszerek alkalmazási gyakoriságának vizsgálatánál nem kellett egyetlen vállalatot sem kizárni az elemzésból. A változók közötti összefüggések feltárásához a varianciaanalízis módszerét alkalmaztuk. A vizsgált függô változók megfeleltek a varianciaanalízis feltételeinek (normál eloszlás és szóráshomogenitás).

A témához tartozó szakirodalmi vélemények leginkább a hatalmi viszonyok és a vállalati teljesítmények közötti kapcsolat vonatkozásában oszlanak meg. Egyes szerzók (Kumar et al., 1996; Maloni - Benton, 2000; Benton - Maloni, 2005) pozitív kapcsolatot, míg mások (Caniels - Gelderman, 2007) negatív összefüggést tártak fel az erófölény teljesítményre gyakorolt hatásánál. Mi a jövedelmezóségi mutatókra elvégzett varianciaanalízis nullhipotézisét (3. melléklet) elfogadtuk, 
miszerint nincs különbség az egyes kezelési csoportok átlagai között. Ez azt jelenti, hogy nincs szignifikáns különbség azon vállalatok jövedelmezóségi mutatói között, amelyek eltérô hatalmi pozícióval (alárendelt, egyenrangú, domináns) jellemezhetốk. Ez a megállapítás igaz mindkét mutató esetében (ROE: 0,7926>0,05, ROA: 0,2907>0,05).

A második feltételezésünket azonban a varianciaanalízis eredményei igazolták (3. melléklet), miszerint a jellemzően domináns pozícióban lévő kis- és középvállalkozások gyakrabban alkalmaznak korszerú ellátási láncbeli módszereket, mint az alárendelt hatalmi viszonnyal jellemezhetô KKV-k. Ez a megállapítás mind a vevői, mind a beszállítói oldalon igaz, hiszen mindkét vizsgált változó esetében szignifikáns a különbség. A kapott eredmény tehát szignifikáns ugyan, de ez még csak azt jelzi, hogy a kategóriák (alárendelt, egyenrangú, domináns) átlagai között általában van eltérés, azt azonban nem tudjuk, hogy pontosan mely átlagok között van. A kérdés megválaszolásához az úgynevezett Scheffe-próbát (4. melléklet) végeztük el, amely az átlagok minden lehetséges páros kombinációjára egyidejú páros összehasonlításokat végez.

A Scheffe-próba eredményei azt mutatják, hogy beszállítói oldalon a domináns vállalatok átlagai szignifikánsan eltérnek mind az egyenrangú, mind az alárendelt vállalatok átlagaitól, vagyis a hatalmi fölényben lévő kis- és középvállalatok beszállítói oldalukon lényegesen gyakrabban alkalmaznak korszerú ellátási láncbeli módszereket, mint a másik két kategóriába tartozó vállalatok. Ennek oka lehet, hogy a domináns vállalatok közelebb helyezkednek el a végső fogyasztókhoz, nagyobbak, míg az alárendelt hatalmi pozíciójú vállalatok kisebbek, és inkább az ellátási láncok downstream szakaszán helyezkednek el alapanyagvagy nyersanyagtermelốként. A vevői oldalon szignifikáns különbség csak a domináns és az egyenrangú csoportok között mutatható ki.

Összességében elmondható, hogy a domináns csatornatagok gyakrabban élnek a korszerú ellátási láncbeli megoldások lehetőségeivel, ami feltételezhetően több tényezőre vezethetô vissza, mint például tốke, fontos piaci információk birtoklása, méret stb.

\section{Összefoglalás, további kutatási irányok}

A vizsgálatban szereplő élelmiszer-ipari kis- és középvállalkozásoknál a partnerkapcsolatokban betöltött hatalmi pozíció befolyást gyakorol több, a vállalatok ellátási láncbeli múködését befolyásoló tényezőre, így például az együttmúködések tartósságára és szorosságára, valamint a vevối és beszállítói oldalon alkalma- zott korszerú ellátási láncbeli megoldások alkalmazási gyakoriságára.

Kutatásunk során beszállítói oldalon nem találtunk összefüggést a hatalmi pozíció és az együttmúködések szorossága között, míg vevôii oldalon szignifikáns kapcsolatot tapasztaltunk a két vizsgált tényező között. Azok a vállalatok, amelyek jellemzóen alárendeltnek ítélik meg az ellátási láncbeli partnerkapcsolataikban betöltött szerepüket, hosszabb távú kapcsolatokra törekednek vevốikkel és szorosabb együttmúköódési formákat alakítanak ki velük. A dominánsabb vállalatok viszont vevőik irányába lazább partnerkapcsolatokkal jellemezhetốk, és kevésbé jellemzố rájuk a hosszabb távú vevơi kapcsolatok kialakítása.

Továbbá azt is igazoltuk, hogy a jellemzóen domináns pozícióban lévố kis- és középvállalkozások beszállítói oldalon gyakrabban alkalmaznak korszerú ellátási láncbeli módszereket, mint az alárendelt vagy egyenrangú hatalmi viszonnyal jellemezhetô KKV-k. Ugyanezen feltevést vevői oldalon nem sikerült egyértelmúen bizonyítanunk. Emellett - szemben néhány nemzetközi kutatási eredménnyel - nem találtunk szignifikáns kapcsolatot a partnertól való függőség mértéke és a vállalati jövedelmezôség között sem. Eredményeink több újabb feltételezést vetnek fel, amelyek alátámasztása további vizsgálatokat, újabb személyes interjút igényel a kérdőívet kitöltô vállalatok vezetôivel.

Véleményünk szerint a szektor domináns csatornatagjainak a hatalom azon típusait (jutalmazó, információs) kellene gyakorolniuk, amelyek ösztönzóleg hatnak a gyengébb hatalmi pozíciójú lánctagokra. Így a hatalom gyakorlása révén a partnerek közötti bizalom fokozható, az információmegosztási hajlandóság, az együttmúködések tartóssága növelhetố lenne. A gyengébb hatalmi pozícióval rendelkezô kis- és középvállalatoknak pedig nem feltétlenül a domináns nagyvállalatokkal való együttmúködési lehetôségeket kellene keresniük (vállalva számos kényszermegoldást és költséget) a nagyobb teljesítmény reményében. Ehelyett hatalmi pozíciójuk erôsítésének, teljesítményük növelésének eszközei lehetnének a horizontális együttmúködési formák keresése vagy az innovációs tevékenység erôsítése (ezáltal például szakértői vagy referens hatalom szerzése).

Jelenleg folyik a magyarországi vizsgálatunkban használt kérdőív lekérdezése a német (bajorországi) FMCG/Food szektor kis- és középvállalkozásai körében, amelynek eredményeit felhasználva egy összehasonlító elemzést tervezünk készíteni a magyarországi és a németországi KKV-szektor élelmiszer-ipari szereplői között. 


\section{Lábjegyzet}

${ }^{1}$ Ennek gyakorlati alátámasztását (sörjáték) lásd például Kovács (2010)

\section{Felhasznált irodalom}

Anderson, E. - Weitz, A.B. (1992): The Use of Pledges to Build and Sustain Commitment. Journal of Marketing Research, 24: p. 18-34.

Barber, E. (2011): Strategic Approaches to Domination in Supply Chains. in: Renko, S. (edit.): Supply Chain Management - New Perspectives. Rijeka: InTech: p. 167-182.

Belaya, V. - Hanf, J.H. (2009): Power Struggle in the Food Chain? Lessons from Empirical Studies on Power Influences in Chains and Marketing Channels. 113th EAAE Seminar "A resilient European food industry and food chain in a challenging world", Chania, Crete, Greece, September 3-6, 2009: p. 1-33.

Belaya, V. - Hanf, J.H. (2011): Power and Supply Chain Management-InsightsfromRussia, Vortrag anlässlichder 51. Jahrestagung der GEWISOLA ,Unternehmerische Landwirtschaft zwischen Marktanforderungen und gesellschaftlichen Erwartungen“, Halle, 28. bis 30. September 2011: p. 1-13.

Brown, J.R. - Lusch, R.F. - Nicholson, C.Y. (1995): Power and relationship commitment: Their impact on marketing channel member performance. Journal of Retailing, 1995, 71(4): p. 363-392.

Benton, W. C. - Maloni, M. (2005): The influence of power driven buyer/seller relationships on supply chain satisfaction, Journal of Operations Management, (23): p. 1-22.

Caniels, M.C.J. - Gelderman, C.J. (2007): Power and interdependence in buyer supplier relationships: A purchasing portfolio approach. Industrial Marketing Management, 36 (2): p. 219-229.

Choudhury, B. - Agarwal, Y.K. - Singh, K.N. Bandyopadhyay, D. K. (2008): Value of Information in a Capacitated Supply Chain. INFOR, Vol. 46, No. 2: p. 117-127.

Cox, A. - Lonsdale, C. - Watson, G. - Qiao, H. (2003): Supplier Relationship Management: A Framework for Understanding Managerial Capacity and Constraints. European Business Journal, Vol. 15, No. 4: p. 135-145.

Demeter K. - Gelei A. - Jenei I. (2004): A vállalati stratégia hatása az ellátásilánc-menedzsment eszközeire. Vezetéstudomány, 35. k. 2004. április: p. 33-47.

Földesi, P. - Botzheim, J. - Süle, E. (2011): Representation of Loss Aversion and Impatience Concerning Time Utility in Supply Chains. Smart Innovation, Systems and Technologies, Volume 10: p. 273-282.

Gelei A. (2003): Az ellátási lánc típusai és menedzsment kérdései. Vezetéstudomány, 34. k. 2004. júliusaugusztus p. 24-34.
Goodman, L.E. - Dion, P.A. (2001): The determinants of commitment in the distributor-manufacturer relationship. Industrial Marketing Management, 2001, 30(3): p. 287-300.

Govil, M. - Proth, J.M. (2002): Supply Chain Design and Management: Strategic and Tactical Perspectives. San Diego: Academic Press: p. 145-168.

Harris, L.M. - McDowell, C.W. - Gibson, G.S. - Cooke, N.B. (2011): SMEs and Performance: The Role of Trust and Dependence in the Supply Chain. USASBE 2011 Proceedings: p. 887-898.

Hingley, M.K. (2005): Power imbalanced relationships: Cases from UK fresh food supply. International Journal of Retail \& Distribution Management, 33 (8): p. 551-569.

Huo, B. - Zhao, X. - Yeung, J.H.Y. (2005): Power, Relationship Commitment and Supply Chain Integration Between Manufacturer and Supplier. Proceedings of the Fifth International Conference on Electronic Business, Hong Kong, December 5-9, 2005: p. 868-881.

Kovács Z. (2010): Egy ellátási lánc szimulációjának tapasztalatai. Vezetéstudomány, XLI. évf. 10. sz.: p. 52-61.

Kumar, N. - Sheer, L.K. - Steenkamp, B.E.M. (1995): The Effects of Perceived Interdependence on Dealer Attitude. Journal of Marketing Research, 32, August: p. 348-358.

Kumar, N. (1996): The power of trust in manufacturerretailer relationships. Harvard Business Review, 74, (6): p. $92-106$.

Liker, J.K. - Choi, T.Y. (2004): Building Deep Supplier Relationships. Harvard Business Review, Dec., Volume 82, Issue 12: p. 104-112.

Maloni, M. - Benton, W.C. (2000): Power Influences in the Supply Chain. Journal of Business Logistics, Vol. 21. No. 1: p. 49-74.

McDowell, C.W. - Harris, L.M. - Gibson, G.S. (2010): The Role of Trust and Dependence in Small Business Performance: Does Size Matter?, USASBE 2010 Proceedings: p. 937-950.

Mukhtar, M. - Shaharoun, A.M. (2002): Supply Chain Relationship Structures as Scenarios for simulation. Proceedings 14th European Simulation Symposium: p. $1-5$.

Pénzes I.R. (2009): A beszerzési koncentráció hatása az üzletláncok marketingtevékenységére. Szolnoki Tudományos Közlemények: p. 1-10.

Sangway, K.S. (2006): Performance Value Analysis for Justification of Green Manufacturing Systems. Journal of Advanced Manufacturing Systems, Vol. 5: p. 59-73.

Schubert A. (2007): Analysing supply chain partnerships in the Hungarian FMCG-sector, Múhelytanulmány (working paper). Budapest: Budapesti Corvinus Egyetem, Vállalatgazdaságtan Intézet: p. 1-16.

Selldin, E. - Olgaher, L. (2007): Linking Products with Supply Chains: Testing Fisher's Model. Supply Chain Management: An International Journal, Vol. 12, No.1: p. $42-51$. 
Simatupang, T.M. - Wright, A.C. - Sridharan, R. (2004): Applying the theory of constraints to supply chain collaboration. Supply Chain Management: An International Journal, Vol. 9, No. 1: p. 57-70.

Skinner, J.S. - Gassenheimer, B.J. - Kelley, W.S. (1992): Cooperation in Supplier-Dealer Relations. Journal of Retailing, 68, No. 2: p. 174-193.

Skjott-Larsen, T. (2006): Battle of the Supply Chains. European Business Journal, Vol. 24, Spring: p. 43-48.

Smith, K. - Lawrence, G. - Richards, C. (2010): Supermarkets' Governance of the Agri-food Supply Chain: Is the 'Corporate-Environmental' Food Regime Evident in Australia?, International Journal of Soc. of Agr. \& Food, Vol. 17, No. 2: p. 140-161.

Szegedi Z. (2008): Logistics in Small and Medium Companies in Central and Eastern Europe. International Journal of Procurement Management, Vol. 1, No. 3: p. 359-370.
Szegedi Z. (2012): Ellátásilánc-menedzsment - Elmélet és gyakorlat. Budapest: Kossuth Kiadó: p. 19-36., 160-162. Vereecke, A. - Muylle, S. (2006): Performance improvement through supply chain collaboration in Europe. International Journal of Operations \& Production Management, Vol. 26, No. 11: p. 1176-1198.

Wang, J.C. - Lau, H.S. (2008): How a Retailer Should Manipulate a Dominant Manufacturer's Perception of market and Cost Parameters. International Journal of Production Economics, Vol. 116: p. 43-60.

Wang, X. - Liu, L. (2007): Coordination in a Retailer-Led Supply Chain Through Option Contract. International Journal of Production Economics, Vol. 110: p. 115-127.

Zhou, N. - Zhuang, G. - Yip, L. S.-c. (2007): Perceptual difference of dependence and its impact on conflict in marketing channels in China: An empirical study with two-sided data. Industrial Marketing Management, 36 (3): p. 309-321.

\section{MELLÉKLETEK}

\section{A tanulmányhoz kapcsolódó kérdőívrészlet}

\section{Hogyan alakulnak a hatalmi viszonyok az Önök ellátási láncában? Kérem, állítson fel egy hatalmi} sorrendet, sorszámozza a lánctagokat 1-tól 3-ig (1: leginkább domináns, 3: legkevésbé domináns)!

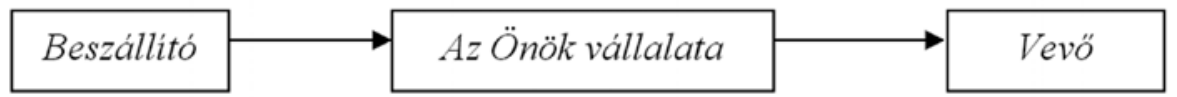

Sorszám:
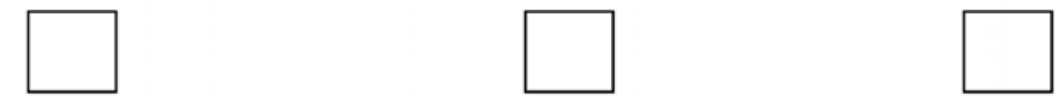

2. Miben nyilvánul meg az 1-es sorszámmal megjelölt lánctag dominanciája?

(Kérem, $X$-szel jelölje, több választ is megjelölhet!)

árban diktál

szállítási feltételekben (határidô, mennyiség) diktál

alkalmazott technológiában diktál (raklap, vonalkód, RFID alkalmazását ráerólteti a partnerre stb.)

fizetési feltételekben $(60 / 90 \ldots$ nap stb.) diktál

egyéb:.

3. Hogyan ítéli meg az Önök vállalatának partnerkapcsolataiban betöltött hatalmi szerepét

(a partnerkapcsolatokat egyenként vizsgálva, függetlenül attól, hogy beszállitói vagy vevói kapcsolatról van szó)?

Kérem, válaszát az összes kapcsolat arányában adja meg (osszon fel 100\%-ot)!

Az Önök vállalata az összes partnerkapcsolatának

\%-ban domináns

\%-ban egyenrangú

\%-ban alárendelt szerepet tölt be.

VEZETÉSTUDOMÁNY 


\section{Az egyes változókra elvégzett összefüggés-vizsgálatok eredményei}

\begin{tabular}{|c|c|c|c|c|c|}
\hline Függő változók & Mutatók & $\begin{array}{c}\text { Szignifikancia- } \\
\text { szint }\end{array}$ & Függö változók & Mutatók & $\begin{array}{c}\text { Szignifikancia- } \\
\text { szint }\end{array}$ \\
\hline \multirow{3}{*}{$\begin{array}{l}\text { A kapcsolat szorossága } \\
\text { beszállítói oldalon }\end{array}$} & Pearson Chi-Square & 0,2127 & \multirow{3}{*}{$\begin{array}{l}\text { Stratégiai helyzet } \\
\text { megítélése }\end{array}$} & Pearson Chi-Square & 0,1568 \\
\hline & Likelihood Ratio & 0,3146 & & Likelihood Ratio & 0,1517 \\
\hline & Linear-by-LinearAssoc. & 0,6630 & & Linear-by-LinearAssoc. & 0,0146 \\
\hline \multirow{3}{*}{$\begin{array}{l}\text { A kapcsolat } \\
\text { szorossága vevői } \\
\text { oldalon }\end{array}$} & Pearson Chi-Square & 0,0022 & \multirow{3}{*}{$\begin{array}{l}\text { Információmegosztási } \\
\text { hajlandóság }\end{array}$} & Pearson Chi-Square & 0,2644 \\
\hline & Likelihood Ratio & 0,0012 & & Likelihood Ratio & 0,2468 \\
\hline & Linear-by-LinearAssoc. & 0,0055 & & Linear-by-LinearAssoc. & 0,1061 \\
\hline \multirow{3}{*}{$\begin{array}{l}\text { A bizalom foka } \\
\text { (beszállítói oldal) }\end{array}$} & Pearson Chi-Square & 0,2326 & \multirow{3}{*}{$\begin{array}{l}\text { A kapcsolat tartóssága } \\
\text { (beszállítói oldal) }\end{array}$} & Pearson Chi-Square & 0,0000 \\
\hline & Likelihood Ratio & 0,3229 & & Likelihood Ratio & 0,0000 \\
\hline & Linear-by-LinearAssoc. & 0,3766 & & Linear-by-LinearAssoc. & 0,0000 \\
\hline \multirow{3}{*}{$\begin{array}{l}\text { A bizalom foka } \\
\text { (vevői oldal) }\end{array}$} & Pearson Chi-Square & 0,1492 & \multirow{3}{*}{$\begin{array}{l}\text { A kapcsolat tartóssága } \\
\text { (vevői oldal) }\end{array}$} & Pearson Chi-Square & 0,0000 \\
\hline & Likelihood Ratio & 0,2735 & & Likelihood Ratio & 0,0000 \\
\hline & Linear-by-LinearAssoc. & 0,0495 & & Linear-by-LinearAssoc. & 0,0011 \\
\hline
\end{tabular}

Forrás: saját számítás, 2013

3. melléklet

\section{A varianciaanalízis ANOVA-táblája}

\begin{tabular}{|l|c|c|}
\hline \multicolumn{1}{|c|}{ Függó változók } & F próba & Szignifikanciaszint \\
\hline Sajáttő́ke-arányos nyereség (ROE) & 0,2327 & 0,7926 \\
\hline Eszközarányos nyereség (ROA) & 1,2449 & 0,2907 \\
\hline Ellátási láncbeli módszerek alkalmazási gyakorisága (beszállítói oldal) & 8,0636 & $\mathbf{0 , 0 0 0 4}$ \\
\hline Ellátási láncbeli módszerek alkalmazási gyakorisága (vevói oldal) & 3,6503 & $\mathbf{0 , 0 2 7 8}$ \\
\hline
\end{tabular}

Forrás: saját számítás, 2013

\section{Scheffe-próba}

\begin{tabular}{|c|c|c|c|}
\hline Függố változók & $\begin{array}{l}\text { (I) Függés } \\
\text { a partnertól }\end{array}$ & $\begin{array}{l}\text { (J) Függés } \\
\text { a partnertốl }\end{array}$ & $\begin{array}{c}\text { Szignifikancia- } \\
\text { szint }\end{array}$ \\
\hline \multirow{6}{*}{$\begin{array}{l}\text { ellátási láncbeli módszerek alkalmazási gyakorisága } \\
\text { (beszállítói oldal) }\end{array}$} & \multirow{2}{*}{ alárendelt } & egyenrangú & 0,9112 \\
\hline & & domináns & 0,0091 \\
\hline & \multirow{2}{*}{ egyenrangú } & alárendelt & 0,9112 \\
\hline & & domináns & 0,0008 \\
\hline & \multirow{2}{*}{ domináns } & alárendelt & 0,0091 \\
\hline & & egyenrangú & 0,0008 \\
\hline \multirow{6}{*}{$\begin{array}{l}\text { ellátási láncbeli módszerek alkalmazási gyakorisága } \\
\text { (vevôi oldal) }\end{array}$} & \multirow{2}{*}{ alárendelt } & egyenrangú & 0,9451 \\
\hline & & domináns & 0,1092 \\
\hline & \multirow{2}{*}{ egyenrangú } & alárendelt & 0,9451 \\
\hline & & domináns & 0,0380 \\
\hline & \multirow{2}{*}{ domináns } & alárendelt & 0,1092 \\
\hline & & egyenrangú & 0,0380 \\
\hline
\end{tabular}

Forrás: saját számítás, 2013 